\title{
The emergence of pensioners' parties in contemporary Europe
}

Chapter 12 in Joerg Chet Tremmel (ed.) Young Generation Under Pressure? The Financial Situation and the "Rush Hour" of the Cohorts 1970-1985 in a Generational Comparison. Berlin: Springer Verlag, 2010, pp. 225-244.

Dr Seán Hanley

Senior Lecturer in Politics

School of Slavonic and East European Studies

UCL

Gower St

London WC1E 6BT

s.hanley@ssees.ucl.ac.uk

tel + 00442076798818 


\section{The emergence of pensioners' parties in contemporary Europe}

\section{Introduction}

Party politics in contemporary Europe often exhibit marked generational biases. Older voters are both more to turn out to vote to support political parties at elections and to be members of political parties (Goerres 2009). Conversely, younger votes are increasingly disinclined to participate in formal party-electoral politics leading to concern over the 'greying' of party democracy and of socio-political organizations (Henn, Weinstein and Wring 2002; Phelps 2006; Goerres 2009; Robertson 2009). Certain (types of) party are disproportionately supported by older age groups. Indeed, in certain cases - as with the members of the British Conservative Party during 1990s (Whitely, Syed and Richardson 1994) or the electorate of the Czech Republic's Communist Party (Hanley 2001), older age cohorts can find themselves in the majority, significantly affecting the way such parties understand, prioritize and respond to issues of the day and often tending to narrow their political appeal over time.

However, the possibility that population ageing and the growing salience of issues relating to ageing societies might generate pressures for the emergence of new parties has been largely overlooked. This is in many ways unsurprising. Despite the emergence at the margins of political systems across Europe of pensioners and retirees' parties over the last two decades years, such 'grey interest' parties' (Goerres 2006: 148), appear on first examination a fringe phenomenon of little importance (Walker 1998; Goerres 2009: 72-4). ${ }^{1}$ Nevertheless, grey interest parties arguably merit closer examination both as socio-political phenomena in themselves and as a potential new party family in the making in European politics. As Herzog (1987) suggests, regardless of their vote-getting potential, newly emerging minor parties can serve as a marker for emergence of new issues and an early indicator that (wider) groups of voters may be re-defining and re-negotiate socio-political identities or seeking vehicles for protest. Moreover, in a number of European states grey interest parties have already enjoyed sufficient electoral success to exercise political leverage. Indeed, a small number of cases, they have even entered government.

This chapter maps the emergence of pensioners' parties over the last two decades in both established West European democracies and the newer post-communist democracies of Central and Eastern Europe (CEE). It then examines the reasons for the emergence and, in certain cases, the relative success of pensioners' parties highlighting both the 'demand' for such parties generated by socio-economic and demographic change and the of 'supply' political opportunity for their emergence thrown up by electoral systems and configurations of established parties. It concludes with a brief assessment of the prospects of pensioners' parties and the possibility that they might establish themselves as a minor party family in European politics.

\section{The emergence of pensioners' parties}

\footnotetext{
${ }^{1}$ Following Goerres (2009: 72), I take a 'grey interest' party to be any organization contesting (or planning to contest) elections which signals through its name and/or founding documents that it seeks mainly to represent the interests of pensioners and/or older voters.
} 
Pensioners' interest organizations in Western Europe generally date from 1940s and 1950s and in some cases the interwar period. The precise form of such organizations varied both historically and by national context, reflecting specific patterns of 'pillarization' and/or 'partification' of social life or specific strategies of mass organization. A further wave of new older people's social and political organizations emerged sporadically across from 1970s across Western Europe in the context of the 'new politics of old age' generated by the twin processes of population ageing and the contraction and reconfiguration of post-war welfare states (Walker 1998; Ever and Wolf 1999).

In West European democracies, pensioners' parties emerged as a fringe phenomenon in late 1980s and early 1990s. Although there were reports of an 'Autonomous Party of Pensioners' contesting Italian parliamentary elections as early as 1972 (Time, 22 March 1972, as table 1 shows, the first pensioners' party to emerge in a Western democracy for which firm evidence is available was founded in Israel in 1981 - the first in a series of generally peripheral 'grey' groupings to emerge in Israeli electoral politics before the unexpected electoral breakthrough of the GIL party in 2006 (Iecovich 2002; Derfner 2006; Susser 2007). The first grey party to emerge in Western Europe proper was Italy's Partito dei Pensionati (PP) founded in 1987. Thereafter pensioners' parties were formed in Germany, Scandinavia, the Benelux countries and Portugal. More recently, several pensioners' parties have also emerged seem the United Kingdom. The Scottish Senior Citizens' Unity Party (SSCUP) was founded in 2003 and had one representative elected to the Scottish Parliament in elections of that year. Several more peripheral and localized groups emerged in England and Wales around the time of the 2005 general election. Overall, it appears only three countries in Western Europe saw no grey interest parties form: Ireland, Iceland and France.

\section{[TABLE 1 ABOUT HERE]}

As table 1 shows West European pensioners' parties have so far remained a largely peripheral phenomenon. Some have almost no electoral support at national level, although most have been able to gain 1-2 per cent of the vote in national elections on at least one occasion and many have some representation at sub-national level. A small number of 'grey' parties have exceeded this level of support, the most notable cases being Holland's General Elderly Alliance (AOV) (van Stipdonk and van Holsteyn 1995; Thornton 1995), which was represented in the Dutch parliament between 1994 and 1998, and Luxembourg's Alternative Democratic Reform Party (ADR) which has polled close to 10 per cent of the national vote in successive parliamentary elections and has become an established parliamentary party. In neither case, however, did these grey interest groupings enter government, nor were they considered as potential coalition partners. Israel thus offers the only instance of a pensioners' party holding government office in an established Western democracy. The Israeli pensioners' party GIL which was represented in the Knesset between 2006 and 2009 was a junior partner in the coalition administration led by the centrist Kadima movement. Pensioners' parties have also contested European elections on several occasions. However, only one, Italy's Partito dei Pensionati (PP) which gained one MEP in 2004, has had any representation in the European Parliament. 
Pensioners' parties have also widely emerged in post-communist Europe but, as in Western Europe, been have remained a largely peripheral and short-lived phenomenon. As table 2 shows 'grey' groupings formed in almost all post-communist democracies in CEE, the earliest emerging in the early-mid 1990s in he rapidly reforming Central European states. Pensioners' parties have also developed more recently in Russia, Ukraine and South East European states such Croatia, Serbia and Bulgaria, where the region's newest grey party, the Social Solidarity Movement, was founded in July 2007 after months of protest demonstrations by older people in Sofia against the Bulgarian government's failure to uprate pensions (Novinite 2007). In post-communist Europe, despite the existence of numerous electoral lists for the 'underprivileged' or 'social justice', pensioners' parties seem to be absent in Albania, Latvia, Lithuania and Moldova.

\section{[TABLE 2 ABOUT HERE]}

As in Western Europe, the success of Eastern and Central Europe's grey interest parties has been limited and few have established themselves on a longer term basis. Many, such as Hungary's National Pensioners' Party or Slovakia's two short-lived pensioner groupings, appear effectively defunct, while others have merged, either temporarily or permanently, with larger electoral groupings. In general, however, pensioner parties appeared to perform somewhat more successfully in the postcommunist Central and Eastern Europe than in West European democracies. Several grey groupings in the region performed as credible extra-parliamentary groupings in parliamentary elections in the Czech Republic (1992, 1996 and 1998), Estonia (1993), Poland (1997) often polling 2-3 per cent - a level of support usually sufficient to access state funding and offer a realistic chance of crossing electoral thresholds. Pensioners' parties have entered national parliaments in four post-communist states (Russia, Slovenia, Croatia, and Serbia).

Of these three have been represented in a government, the Democratic Party of Pensioners of Slovenia (DeSUS) has held government office as junior partner in coalitional governments of left and right for more than a decade. Having increasing its vote from 4.04 per cent to 7.47 per cent in the 2008 parliamentary elections, DeSUS is currently a partner in Slovenia's centre-left coalition government and has two ministerial portfolios. Similarly, the Party of United Pensioners of Serbia (PUPS) also won parliamentary representation in Serbia's 2008 parliamentary elections as part of coalition led by the Socialist Party of Serbia and subsequently entered government when this bloc became a junior member of the pro-European administration of Prime Minister Mirko Cvetković. The party's leader Jovan Krkobabić is currently a Deputy Prime Minister and has responsibility for several social affairs portfolios. The Croatian Pensioners' Party (HSU), which unexpectedly entered parliament in 2003 and retained one deputy in 2007 elections, has also exercised some influence on government acted as a 'support party' for successive administrations led by the reformed nationalist Croatian Democratic Union (HDZ).

\section{Ideology and impact}

In both Western and Eastern European pensioners' parties articulate straightforward (usually short-term) material demands linked to distributional issues and represent themselves as a non-partisan voice for 'old folk' generally, in a way which gives them 
a degree of legitimacy and insulation from political attack. Their demands have centred on a series of essentially similar concerns: higher (and more regularly and effectively uprated) pensions; improvements in public services heavily used by older people such as health, social care and public transport; reductions in tax or reduced charges for public services for old people; and measures to combat age discrimination and change the social climate to give greater recognition and status to older people. Such demands are usually been expressed in short programmatic statements, which do not generally attempt to develop broader policy prescriptions or formulate detailed ideological standpoints.

At the same time, however, most pensioners' parties seek to represent themselves as more something more than mere sectional interest. Some project themselves as reformers contributing to the general debate about social cohesion and intergenerational solidarity. The slogan of Germany's Die Grauen 'Us today, you tomorrow', for example, sought to highlight that the party was defending the status of older people and the services and institutions they used on behalf of all citizens, who will inevitably pass through retirement and old age one day. German Greys have now described their party as a 'Party of Generations' (Generationenpartei). ${ }^{2}$ Other grey interest parties have sought to identify themselves as part of broader movements for social justice or social welfare, making common cause with other groups dependent on transfers from the state, such as disabled people, carers or single parents. This trend especially marked in Central and Eastern Europe where such groups are often seen as among the hardest hit of 'transition losers'.

The political leverage that 'grey interest' parties been able to exercise exercised has been limited, but not non-existent. An unexpectedly high vote for a novel political formation like pensioners' party, even of a few percent, receives disproportionate publicity and can be taken as a signal by established parties already highly sensitised to the (largely erroneous) notion of a powerful 'grey vote' (Vincent, Patterson and Wale 2001; Goerres 2009; Tepe and Vanhuysse 2009). that they should attend more closely to demands and interests of older and retired voters. In addition the 'blackmail potential' derived from taking votes from other parties, 'grey interest' parties which gain parliamentary representation can often enjoy quite significant 'coalition potential' with both left and right as potential junior partners in government: especially in finely balanced political systems, grey interest parties' smallness, lack of ideological profile and focus on specific (and hence negotiable) redistributive demands generally makes them attractive to both left and right as possible junior partners in government. Slovenia's DeSUS, for example, has participated in three successive coalition governments, of centre-left, centre- right and centre-left respectively. ${ }^{3}$

\footnotetext{
${ }^{2}$ Founded as a party in 1989, Die Grauen formally dissolved in February 2008 in consequence of party funding scandal (Kölnische Rundschau 2007), but has been replaced by two successor pensioners' parties: the Die Grauen - Generationspartei and the Allianz Graue Panther. The former, whose leader are significantly younger than retirement age, is committed to the 'grey populist' strategy described later in this paper.

${ }^{3}$ Similarly, Italy's small Partito dei Pensionati has shuttled between the right-wing Pole of Liberty bloc with whom it was allied in the 2001 parliamentary elections and its centre-left rival the L'Unione/Olive Tree coalition, which the PP joined in February 2006 before leaving to rejoin the Pole of Liberty (later People of Freedom (PDL) in November 2006. In the June 2009 European elections,
} 
Once in office pensioners' parties, although they lack wide- political influence, are often able to extract specific or short-term concessions relating to the material or institutional support of older people. During its short tenure in government, Israel's GIL party, for example, used its control the health and pensions ministries to help launch a new plan with a budget of 7 million shekels to improve medical care for the elderly, centring on rehabilitation plans operating in and across hospitals, private homes and the wider community (Azoulay 2007). Similarly, in 2008 Serbia's PUPS blocked the rescinding of a ten per cent increase in pensions agreed as part of a package of spending cuts required for Serbia to obtain an IMF loan. Instead, public sector salaries were frozen to achieve the required spending reductions with pensions frozen in the subsequent year (Javno 2008).

\section{Explaining pensioners' parties}

How and why have pensioners' parties have formed? And why have some been more successful than others? The academic literature on new parties, broadly agrees that three sets of conditions are important for the development of new types of party: 1) new or unmet demands for political representation generated by changes in underlying socio-economic, demographic and family structures; 2) political institutions and patterns of political competition that present a favourable set of 'opportunity structures' for new parties seeking to enter the political arena; and 3) the mobilization and co-ordination of sufficient material and human resources (Harmel and Robertson 1985; Willey 1998; Kitschelt 1989, 2007; Redding and Viterna 1999; Hug 2001; Sikk 2005; Tavits 2006, 2008)

\section{Population ageing}

The most basic social trend in post-industrial societies that might underlie the emergence of pensioners' parties is the growing numbers of older and retired people in European societies. This, it may be hypothesized, would generate both strong resource demands and demands for greater participation by older people leading to a new, more contested politics of old age (Walker 1998) At one level, demographic ageing seems a highly relevant factor. Certainly, the non-emergence of pensioners' parties in Ireland and Iceland, the two West European states with lowest proportions of older and retired people, is perhaps not coincidental

However, the development of pensioners' parties cannot be accounted for simply by raw demographic change. In some contexts, there is only very slight correlation between demographic ageing and the proportion of pensioners in the population. In some Central and Eastern European states in 1990s, for example, numbers of older people and numbers of retirees diverged significantly as a result of an artificially induced' pensioner boom' stemming from the use of generous early retirement schemes to facilitate industrial restructuring and pre-empt social discontent following the fall of communism (Vanhuysse 2006). Similar, if less marked divergence can also be found in many West European countries (Kubitza 2005). A change of focus to

the party formed part of the heterogeneous Pole of Autonomies coalition, but its MEP was not reelected. 
numbers of pensioners rather than older people, however, also offers only partial explanation. Israel, for example, presents an obvious anomaly: it is a case with relatively low proportion retired people compared to other Western democracies, which since 1980s has seen a succession of grey interest parties enter the political arena and on one occasion - that of the GIL party in 2006 - gain sufficient support to enter parliament and enter government. When assessing the drivers of political phenomena thrown up by the new politics of ageing such as pensioners' parties it is therefore important to consider demographic processes of ageing as filtered through political and institutional context(s)

\section{The politics of pensions and welfare}

One such key context is that of the changing welfare state. From the 1980s the focus of welfare politics in Western Europe shifted from one centring on claiming resources and representation in an extensive, expanding welfare state to a 'new politics of welfare focused on their retrenchment and reform (Pierson 1996; Vanhuysse 2001; Green-Pedersen and Haverland 2002). Technological, socio-economic and demographic changes in Western societies have also generated a range of New Social Risks (NSRs) to which welfare systems needed to adapt and reconfigure such as the provision of care for elderly relatives and social protection in a labour market characterized by more patterns of intermittent employment and greater participation of women, (Bonoli 2006). Despite important differences of content, the politics of post-communist welfare and pensions in Central and Eastern Europe have broadly mirrored those in Western Europe. As in Western Europe, CEE welfare states faced a politics of retrenchment and reform of pension and welfare system in the context of market-oriented liberal reforms and demographic change (Pop and Vanhuysse 2004). ${ }^{4}$ However, post-communist societies are generally poorer than those in Western Europe and thus enter the 'new politics of welfare' with fewer resources to manage political change as well more complex tasks in recongfiguring welfare regimes largely inherited from the state socialist period (Mukesh, Betcherman, and Banerji 2007).

The new politics of ageing, welfare and pensions have shaped the development of pensioners' parties in a number of ways. Firstly, age-specific controversies relating to social policy have often acted as trigger events for pensioner party formation, by providing a focus for mobilization and an outlet for deeper sense of social and civic exclusion some seniors feels (usually experienced as various forms of ageism and age discrimination). In some cases, these were widely publicised decisions or debates over policies specifically or disproportionately affecting older people, often coming in a pre-election period. Examples of such trigger events have included proposed cuts to care allowances paid to those in retirement homes (Holland in 1994) or plans to raise retirement ages (misperceived as affecting those approaching retirement), which prompted the foundation of the Scottish Senior Citizens Unity Party (SSCUP).

At a deeper level welfare states can be seen been seen as a key shaper of sociopolitical interests and identities (Campbell 2003), which form the social backdrop to

\footnotetext{
${ }^{4}$ As in Western democracies, post-communist welfare and pension systems in CEE proved resistant to reform efforts, although some states (Hungary 1997, Poland 1998; Latvia 2001; Russia 2002) did introduce pension reforms on World Bank models by creating a second tier of (compulsory) individual accounts
} 
the emergence of pensioner parties. The new politics of welfare have been hypothesized as generating anti-(neo-)liberal distributional demands for the retention of post-war social democratic or social market status quo. Generationally-based conflicts are said to have emerged through the interaction and mutual reinforcement of established welfare and health institutions and a powerful 'grey lobby' able to outcompete other client groups such as families with children or the working poor) in claiming health and welfare resources.

Such competition between beneficiaries of traditional welfare states and younger age groups facing New Social Risks (NSR) -and their different preferences regarding which risks should be prioritized-may, it has been suggested, be destabilising to existing party systems and party alignments. Kitschelt (2004: 9-10), for example, foresees particular problems for Christian Democratic parties in core West European states where, he argues, the development of ageing post-industrial societies will tend to pull apart the these parties' post-war electoral coalitions making it difficult to reconcile pressures from older and retired to maintain benefits from 'old' welfare state structures with pressures to liberalize the economy, curb welfare spending and offset the social risks that younger and middle-aged groups will face. One option, he speculates, might be to jettison social protectionist groups such as (current) pensioners from such coalitions. Such dynamics, if realized, could clearly open up political space for grey interest or other challenger parties. Such generational conflicts are echoed in the transitional politics of Central and Eastern Europe, where pensioners have generally disproportionately protected against the social consequences of market reform than other 'losers' in the reform process such as the unemployed and poorer families with children (Vanhyusse 2006).

\section{Sectoral divisions}

Potential conflicts between generations are, however, often crosscut and inflected by sectoral divisions within generations. Pensioners in established Western democracies encompass diverse sub-groups - from prosperous retirees with generous occupational and private pensions to poor, marginalized older people dependent on state welfare guarantees. Such sectoral divisions seem particularly prominent in Bismarckian welfare states, which have historically offered generous pension benefits to certain sectorally- and gender-defined groups reflecting an organizing principle of maintaining occupational income and status differentials in retirement. ${ }^{5}$

Such sectoral divisions are usually seen as impeding the capacity of pensioners and older people to articulate their interests as a group or take collective action. Older people's interest groups, for example, are often highly fragmented in their agendas and activities, which according to particular strata of older people they focus on and the supporting or sponsoring groups that back them (Evers and Wolf 1999; Viriot Durandal 2003). In the United Kingdom for example, some campaign groups focus on the impact of property taxes on elderly homeowners, while trade union affiliated

\footnotetext{
${ }^{5}$ Conversely where pension provision is more universal and state-centred, retirees may form more homogenous and cohesive group in terms of income, lifestyle and interests. This seems most marked in Central and Eastern, reflecting the lower levels of differentiation of incomes and pension provision under state socialism, the role of the state as the main pension provider and post-transition income maintenance strategies after the fall of communism.(Večerník 2006; Vanhuysse, 2006.
} 
groups focus on state pension indexation and NGOs with charitable status such as Help the Aged concentrated more on standards of social care and social services (Gynn and Arber 1999).

However, the intersection of generational and sectoral divisions can also act as a catalyst for socio-political mobilization. Goerres (2009: 140-59), for example, notes the role of property taxes as focus for protest mobilization by older people in the South West of England. Moreover, the origins of Europe's most successful grey interest party, Luxembourg's Alternative Democratic Reform Party (ADR) - which has polled up to 10 per cent of the national poll and consistently been represented in the Luxembourg legislature since first contesting elections in 1989 - lie in precisely such a confluence of sectoral and generational grievances. The ADR has its origins as the 'Action 'Committee for 5/6 Pensions for Everyone' , which co-ordinated protests in March 1987 by private sector employees (approaching retirement age), trade unions representing the self-employed and private sector pensioners against the more favourable pension regime enjoyed by state employees (Fehlen and Porier 2000: 9198).

\section{Opportunity structures}

However, the shift from lobbying or protest to party-electoral politics and the subsequent limited success of some grey interest grouping also requires explanation in terms of the broader political institutions and sets of opportunity structures facing (prospective) new parties. There is thus broad consensus in the literature that proportional electoral system which set low effective thresholds for parliamentary representation open up opportunities for new parties to enter the political arena. Less fixed and formal institutions such as patterns of party competition or party-society relations are also important. Volatile or fragmented party systems and relatively large numbers of available, weakly committed and/or discontented voters also favour the formation and success of new parties (Willey 1998; Hug 2001; Sikk 2005, 2006). Forms of interest representation represent a further aspect of the political opportunity structures may affect the prospects of emergent new parties. Kitschelt (1989), for example, suggests that strong patterns of corporatism privileging producer groups encourage the development of new parties because new interests struggle to find a voice through existing representation structures. ${ }^{6}$

The opportunities offered to 'grey' parties by varying national political institutions such as electoral and party systems seem, at first sight, to differ little from those faced by other small new emergent parties in general. The success of 'grey' parties in countries with PR systems, very low thresholds, fragmented and changeable party systems and long traditions of minor party formation such as Holland and Israel comes as no surprise. Similarly, the greater prevalence and success of pensioners' parties in Eastern Europe seems closely related to the fluid and changeable nature of party politics in new democracies, especially during their early development (Sikk 2005; Tavits 2008). The initially somewhat blurred distinction between the role and nature of interest organizations and political parties in the region during 1990s

\footnotetext{
${ }^{6}$ Others come to opposite conclusions suggesting that the corporatist-style devolution of power to social partners impedes the development of new parties and makes interest group politics more attractive (Tavits 2006).
} 
(Waller 1993, Lewis 2000) also offered a favourable environment for the development of small interest parties.

However, on closer examination a slightly more complex picture emerges. Many West European states have electoral systems which set relatively low thresholds for representation but have rarely seen new parties emerge from the political fringe. Conversely, while party organizations and systems in Central and Eastern Europe are in many cases more fluid than in the longer established party systems of Western Europe, the high formal electoral thresholds common across the region should represent a substantial obstacle to the development of small niche groupings such as pensioners' parties - and a disincentive to their formation (Birch 2001; Sikk 2005).

Available evidence suggests that corporatist interest intermediation structures (or their absence) may be of limited relevance to the development of grey interest parties. Feltenius (2007) finds that in Sweden, a country with relatively strong corporatist structures, pensioners' interest organizations were effective in lobbying despite lacking formal representation on tripartite bodies. In neighbouring Slovenia, one of the few Central and East European countries with corporatist arrangements, the Slovene pensioners' federation ZDUS has likewise had little difficulty accessing Slovenia's national tripartite body, the Economic and Social Council. ${ }^{7}$ In Slovenia, moreover, the existence of strong, mass interest organization for older people has not precluded the successful development a successful pensioners' party, DeSUS.

Taken together, this evidence suggests that in Western Europe the key impediment to the emergence of relatively successful pensioner parties is the stability of existing parties and, by implication, their ability to appeal to older voters, rather than more formal institutional barriers such as electoral or interest representation systems. In Central and Eastern Europe, by contrast, grey interest parties seems may have been constrained more by their inability to break through formal electoral thresholds. Here, it is perhaps telling that most electorally successful and durable grey interest party in the region, DeSUS, first independently entered the country's parliament in 1996 when the electoral threshold for representation was set at 3.33 per cent (Fink-Hafner 2008).

\section{Mobilizing resources}

Strong social demand and broad institutional opportunities are, however, in themselves insufficient for new parties to emerge. New parties also need access and organize sufficient money, media and human resources and offer policies for which there is electoral demand or a relevant political project (Lucardie 2000). Political entrepreneurs founding new parties also need to effectively co-ordinate their resources to overcome the collective action problems that all newly organizing groups face.

Older people in European societies have historically lacked both significant organizational resources and a distinct socio-political identity, which is a crucial prerequisite for collective action (Dunleavy 1991). Although levels of pension provision vary significantly both cross-nationally and by occupation, older people

\footnotetext{
${ }^{7}$ Author 's telephone interview with the President of ZDUS, Dr Mateja Kozuh-Novak. 19 February 2009.
} 
experience significant reductions in income on retirement and greater levels of ill heath than citizens generally. Although modern welfare and pension systems have helped define the identity of 'senior citizen' or 'elderly person' (Wang 1999), in doing so they have constructed older citizens as passive and needy claimants on the state and society, rather than active political participants. In post-communist Central and Eastern Europe (CEE), moreover, the status of older people in the region has arguably declined for other reasons. Whereas youth in CEE is seen as a repository of liberal values and a crucial factor in bringing about change, older people are typically seen as an obstacle to change: as well as being a significant economic 'loser' group, they are seen as less flexible, as having a psychological stake in the institutions and practices of the communist past.

However, the resources required to found a new small party can be modest requiring a relatively low critical mass of activists, finance and organization, especially in those states where extra-parliamentary parties which meet minimum conditions regarding registration, membership or votes can easily obtain state funding. In Germany, for example, the qualifying threshold for state funding of 0.5 per cent of the vote in national or European parliamentary elections, proved attainable for that country's electorally very marginal pensioners' party, Die Grauen.

There are, moreover, a number of trends mitigating the resource constraints on grey interest mobilization. Current cohorts of older and retired people in most European countries are, however, are healthier, wealthier and better educated than their equivalents in previous decades (Eberstadt and Groth 2007, Goerres 2009). Retired people in Western democracies also have often accumulated sets of experience of civic engagement and professional skills, as well higher levels of free time, which may offset their lower financial and other resources. An established infrastructure of older people's interest and campaign groups working can also provide a potential resource base for the formation of grey interest parties. Such interest groups, although they unusually indifferent or hostile to the notion of grey interest parties can generate individual political entrepreneurs and networks of activists who can act as the founders of such groupings.

This pattern is exemplified in the formation of early West European grey interest parties such as Germany's Die Grauen, Italy's Pensioners' Party or Slovenia's DeSUS which has its origins in a local electoral list fielded in 1988 by frustrated members of the long-established Slovenian pensioners' federation. In a variation on this pattern, older people who had previously been prominent in established parties and social organizations have sometimes acted as early supporters of newly formed grey parties as a means of continuing in public life after retiring from mainstream politics. This pattern can be detected in, for example, the role played in the creation Israeli pensioners' parties of 1980s by former trade union leaders (Iecovich 2002) or in the early momentum gained by the Scottish Senior Citizens Unity Party through the backing of retired local politicians once prominent in the Labour Party (Vincent 2003)

Only in some newer democracies in Central and Eastern Europe where the civic infrastructure for older people - and civil and political society generally - is seriously under-developed does lack of resources seem to have been crucial obstacle impeding the development of grey interest parties. This seems, for example, to have been the case in Bulgaria where regular protest movements against the financial and social 
position of the large older and retired population since 2007 have yet to produce grey interest party capable of contesting national elections.

Media publicity can represent an important start-up resource for overcoming collective action and organizational problems which face small new parties. Given the dominant discourse of 'compassionate ageism' in most European societies, which sees defence of older people's interests an uncontentious non-partisan issue, newly established grey-interest parties can also benefit early media interest and support. Pensioners' parties often have news value as a novelty or serve as focus for populist media campaigning - in South-West England, for example, the activities of the tiny Senior Citizens Party founded in January 2004 were supported and sympathetically reportedly on by the regional Western Daily Press newspaper as part of a campaign to highlight the neglected interests of the elderly (Western Daily Press 2004). However, case studies suggest, sympathetic early media coverage can quickly become hostile if grey interest parties gather political momentum and gain a real prospect of political representation (Vincent 2003).

\section{The political prospects of pensioners' parties}

Do pensioners' parties have any real prospect of emerging as significant political actors? Although the notion of a coherent and powerful 'grey vote' has been shown to largely erroneous (Vincent, Patterson and Wale 2001; Goerres 2009) the growing numbers of older and retired voters in most European electorates and the increased salience of issues related to population ageing suggests that, all other things being equal, grey interest parties will have potential for further growth, especially in political systems that offer favourable institutional environment for new parties. Although political entrepreneurs seeking to establish grey interest parties are likely to face the additional barrier of established party loyalties among older voters developed over a political lifetime, there is some evidence of a nascent 'grey' political consciousness among some older voters. Opinion polling in Western Europe in the late 1990s (Walker 1998) - as well as more recently in Scotland (Help the Aged in Scotland 2005: 34-7) - suggests that large minorities of senior citizens in Europe have at certain points, in principle, been willing to consider supporting a pensioners' party. ${ }^{8}$ Moreover, many current retirees in Western Europe belong to age cohorts socialized in the more participatory, less deferential culture of 1960s when many West European party systems were undergoing dealignment, and may be more open to new political appeals. Similarly, in the new EU member states of Central and Eastern Europe, although older cohorts have undergone different patterns of political socialization to younger voters - and some may have a degree of identification with former ruling communist parties or 'historic' parties with roots in the pre-communist period - the absence of competitive party systems before 1989 has left voter-party linkages across the region comparatively loose.

However, even if they are likely to become more a frequent phenomenon in European politics, grey interest parties seem unlikely to advance beyond minor party status. There are a number of reasons for this. Firstly, although less constraining than

\footnotetext{
${ }^{8}$ Eurobarometer polling date for Western Europe from 1992 cited by Walker (1998) finds that between 14 per cent (Germany) and 42 per cent (Portugal) of those aged over 60 would consider joining an age-based party promoting their interests. The average across the (then) EU12 was 22 per cent
} 
sometimes argued, class, sectoral and social divisions among older people; established political identities and loyalties; and competition for established parties clearly set limits on the ability of grey interest parties to win the support of their chosen constituency. Available case study evidence suggests that grey parties' inroads into the elderly and retired electorate have rarely exceeded 20 per cent. Slovenia's DeSUS, for example, has estimated that it gains about 15 per cent support among older and retired voters (DeSUS 2002). ${ }^{9}$ This suggests that even in ageing democracies where retired and older people form a high and growing proportion of the population- and typically - and make up a still higher proportion of the electorate due to higher rates of turnout (Goerres 2007) - the total potential vote for grey interest parties lies in the region of 5-15 per cent. Even allowing for doubling or trebling of grey parties' ability to convert sympathy into electoral backing that might come with additional finance, better organization or greater professionalism, this implies electoral scores of between 2 and 7 per cent. ${ }^{10}$

\section{Towards a grey populism?}

Some pensioners' parties seem content to play the role of niche minor party groupings representing sub-constituencies of older voters attracted by 'grey' politics. In some cases this because their activity is focused on goals such as winning publicity, rather than challenging for electoral representation. For other more successful groupings such as Slovenia's DeSUS, it reflects caution about changing a formula that has already brought a degree of political success. ${ }^{11}$ Other grey parties, however, have sought to broaden their appeal beyond the claim to be a special representative for older people. Such efforts reflect both the electoral need to boost low levels of voter support and the fact that overtly representing sectional interests in the party political arena is widely seen as less legitimate than general programmatic appeals.

One such strategy for broadening the base of grey interest parties is to link demands on behalf of pensioners and older people with anti-establishment or anti-political protest positions, which likely to appeal to unaffiliated and disaffected voters from other age groups. Some grey interest groups have effected this by simply merging with populist groupings, effectively becoming the 'seniors' platforms' of such protest parties. ${ }^{12}$ Other pensioners' parties have fused grey interest politics and populism in more creative ways. One such example can be founded in the GIL party's successful

\footnotetext{
${ }^{9}$ Similarly, evidence for the Czech Republic suggests that the Czech Pensioners for a Secure Life (DŽJ) party gained no more 13 per cent of pensioners' voters during its best national election performance in 1992 (Kopeček 2005; Večerník 2006: 6) and was favoured by one in five Czech voters aged 60 or above during a short surge in popularity in the run-up to elections in 1998 (Hartl, Huk and Haberlová 1999).

${ }^{10}$ As Mair (2001) notes, on aggregate in West European democracies even large, well established parties such Christian Democrats and Social Democrats only manage to garner the electoral support of around 40 per cent of those who say they potentially sympathetic to these parties.

${ }^{11}$ Interview with the General Secretary of DeSUS Pavel Brglez, Ljubljana, 9 December 2008.

12 For example, in 2005 significant elements of the Antwerp based Flemish pensioners party WOW joined far-right Vlaams Blok (now Vlaams Belang) party contributing to the organization of VB's Seniors' Forum in that city. Similarly, in 2006 Russian Pensioners' Party's merged into the left-wing nationalist Fair Russia (SR) bloc and the Czech Pensioners for a Secure Life (DŽJ) was absorbed by the populist, eurosceptic Independent Democrats party (NEZ).
} 
campaign in Israel's 2006 parliamentary elections, which saw it unexpectedly enter the Knesset. Although GIL polled well in population centres with large retired populations (Izenberg 2006), the party also gained the support of young professional voters in metropolitan districts in Tel Aviv, who reportedly saw GIL as a novel but safe form of protest voting, justifiable as a charitable gesture of solidarity with their grandparents' generation. Indeed, GIL's election strategy consciously sought to combine appeals for justice and empowerment for older people with an irreverent campaign targeted at young voters calling for anti-establishment protest voting (Urquhart 2006; Derfner 2006). ${ }^{13}$

The 3.8 per cent unexpectedly polled by Germany's Die Grauen in the 2006 regional elections in Berlin stemmed from a very similar hybrid strategy combining demands for material improvements for older people; appeals to vote against the corruption and inertia of established parties; and a deliberately controversial poster campaign urging older voters to 'Screw for a Secure Retirement' (McKay 2007; Bekler 2008). A more advanced fusion of populism and 'grey' politics can, however, be found in Luxembourg's ADR, which has shifted from demands for 'pension justice' for those employed outside the state sector towards a more general anti-establishment stance critical of corruption, wasteful public spending and elite projects such as European integration (Fehlen and Poirier 2000: 95-9).

\section{Conclusions}

Over the past two decades pensioners' parties have been a widespread and recurrent minor party phenomenon in both Western Europe and Eastern Europe. Although in most cases they have remained fringe groupings - albeit sometimes of considerable longevity - in a smaller number of cases, they have enjoyed a degree of electoral success, gaining national parliamentary representation and exercised some political influence. 'Grey interest' parties operating at the margins of European party systems, this paper suggests, should be taken seriously and analysed using the broader comparative frameworks used to analyse new party formation.

Although there are considerable - and probably insurmountable - barriers blocking their development into major political actors, given the right institutional and political opportunities grey interest parties can draw on sufficient socio-political demand to establish themselves as minor parties. In this regard the ability of some grey parties to link age-based demands with sectoral or populist discontent with the political systems of ageing democracies may be of particular significance

\footnotetext{
${ }^{13}$ GIL's success in 2006 was also facilitated by the charismatic appeal of its leader, the retired intelligence office Rafi Eitan, well known as the commander of the covert operation in 1960 which abducted Nazi war criminal Adolf Eichmann for trial in to Jerusalem.
} 


\section{References}

Azoulay, Yuval (2007) 'New plan aimed at helping infirm elderly regain independence', Haaretz.com, Online at http://www.haaretz.com/hasen/spages/923554.html (accessed 1 May 2009).

Bekler, Sabine (2008) 'Die Grauen machen weiter', Tagesspiegel, 29 February. Online at http://www.tagesspiegel.de/berlin/art270,2485741 (accessed 3 January 2009).

Birch, Sarah (2001), 'Electoral systems and party systems in Europe East and West', Perspectives on European Politics and Societies, 2 (3), 355-77.

Bonoli, Giuliano (2004), 'The Politics of New Social Risks and Policies', paper prepared for the International Sociological RC, 19th meeting, Paris, 2-4 September.

Campbell, Andrea L, (2003), How Policies Make Citizens: Senior Political Activism in the American Welfare State, Princeton, NJ: Harvard University Press.

Derfner, Larry (2006) 'The grand old party', Jerusalem Post, 6 April (online edition)

DeSUS (2006) 'Izkušnje, poštenost, strpnost, modrost, odprtost', http://www.desus.si/?nav=90\&blog=29\&m=1\# (accessed 1 October 2007).

Dunleavy, Patrick (1991), Democracy, Bureaucracy and Public Choice: Economic Explanations in Political Science, London : Prentice Hall.

Eberstadt, Nicholas and Groth, Hans (2007), 'Healthy Old Europe', Foreign Affairs, May/June 2007.

Evers, Adalbert and Jürgen Wolf (1999) 'Political organization and participation of older people: traditions and changes in five European countries' in Alan Walker and Gerhard Naegele (eds.) in Alan Walker and Gerhard Naegele (eds.) The Politics of Old Age in Europe, Buckingham: Open University Press, 42-61.

Feltenius, David (2007), 'Client organizations in a corporatist country: pensioners' organizations and pensions policy in Sweden', Journal of European Social Policy, 17 (2): 139-151.

Fehlen, Fernand and Porier Porier 1 (2000) Les élections au Grand-Duché de Luxembourg, Rapport sur les élections législatives du 13 juin 1999, Luxembourg: Chambre des deputés. Online at http://www.chd.lu/fr/organisation/documentation/espTele.jsp (accessed 1 July 2007).

Fink-Hafner, Danica (2008) 'Electoral reform in Slovenia: Much ado about nothing', Paper presented at the EPOP conference, Manchester, 12-14 September 2008.

Goerres, Achim (2007), 'Why are Older People more Likely to Vote? The Impact of Ageing on Electoral Turnout across Europe, British Journal of Politics and International Relations, 9 (1): 90-121. 
Goerres, Achim (2009): The Political Participation of Older People in Europe: The Greying of Our Democracies, Basingstoke: PalgraveMacmillan.

Green-Pedersen, Christoffer and Markus Haverland (2002) 'Review essay: The new politics and scholarship of the welfare state, Journal of European Social Policy, 12 (1) 43-51.

Gynn, Jay and Sara Arber (1999), 'The Politics of Old age in the UK' in Alan Walker and Gerhard Naegele (eds.) The Politics of Old Age in Europe, Buckingham: Open University Press, 152-67.

Hanley, Seán (2001), 'Towards Breakthrough or Breakdown? The Consolidation of the KSCM as a Neo-Communist Successor Party in the Czech Republic', Journal of Communist Studies and Transition Politics, 17 (3): 96-116.

Harmel, R. and Robertson J D. (1985) 'Formation and Success of New Parties: A Cross National Analysis', International Political Science Review, 6 (4): 501-23.

Hartl, Jan, Jaroslav, Huk and Věra Haberlová (1999), Česká společnost 1998, Prague: Management Press/STEM.

Help the Aged (2005), 'Council Tax: A Path to Poverty? Help the Aged. Online at http://www.scottish.parliament.uk/business/committees/lg/inquiries/ctax/Help_the_A ged.pdf (accessed 25 October 2007).

Herzog, H (1987), 'Minor Parties: The Relevancy Perspective', Comparative Politics, 19: 3, 317-29.

Hug, Simon (2001) Altering Party Systems: Strategic Behavior and the Emergence of New Political Parties in Western Democracies, Ann Arbor, University of Michigan Press

Kubitza, Arner (2005), 'Pensions in Europe 2002: pension beneficiaries', Statistics in Focus 11/2005, European Commission. Online at http://www.edsdestatis.de/en/downloads/sif/nk_05_11.pdf (accessed 1 June 2009).

Henn, Matt, Mark Weinstein and Dominic Wring, (2002) 'A Generation Apart? Youth and Political Participation in Britain', British Journal of Politics and International Relations, 4 (2): 167-92.

Iecovich, Esther (2002) 'Pensioners' political parties: the Israeli case' in JeanPhilippe Virot Durandal (ed). Cahiers du FIAPA Volume 1: Grey Power? Political Power and influence, Paris: FIAPA, 118-32.

Izenberg, Dan (2006), 'The nuances behind the numbers', Jerusalem Post, 6 April.

Kitschelt, Herbert (1989) The Logics of Party Formation: Ecological Politics in Belgium and West Germany, Ithaca: Cornell University Press. 
Kitschelt, Herbert (2004), 'Diversification and Reconfiguration of Party Systems in Postindustrial Democracies'. International Policy Analysis Unit, Friedrich Ebert Stiftung Online at http://www.fes.de/europolity/finalversionkitsch.PDF (accessed 11 January 2008).

Kitschelt, Herbert (2007) 'Growth and Persistence of the Radical Right in Postindustrial Democracies: Advances and Challenges in Comparative Research', West European Politics 30 (5) 1176-1206.

Kölnische Rundschau (2007) 'Spendenaffäre bei den „Grauen“", 10 October.

Kopeček, Lubomír (2005), 'Strana za životní jistoty’ in J. Malíŕ, P. Marek et al Politické strany: vývoj politických stran a hnutí v českých zemích a Československu, II. díl 1938-2004, Brno: Doplněk, 1633-43.

Javno, 'Serbia Agrees 15-Month IMF Stand-By Deal', 13 November. Online at http://www.javno.com/en-economy/serbia-agrees-15-month-imf-stand-bydeal_203534 (accessed 3 January 2009).

Lewis, Paul (2000) Political Parties in Post-communist Eastern Europe, London: Routledge.

Lucardie, Paul (2000), 'Prophets, Purifiers and Prolocutors: Towards a Theory on the Emergence of New Parties', Party Politics, 6 (2), 175-85.

Lynch Julia (2006), Age in the Welfare State: The Origins of Social Spending on Pensioners, Workers and Children, Cambridge: Cambridge University Press.

McKay, Joanna (2007), 'The Berlin Land Election of 2006', German Politics, 16 (4) 518-25.

Mair, P. (1991) 'The Electoral Universe of Small Parties in Postwar Western Europe' in Ferdinand Müller-Rommel and Geoffrey Pridham (eds.) Small Parties in Western Europe: Comparative and National Perspectives, London: SAGE, 41-70.

Mair, Peter (2001) 'The Green Challenge and Political Competition: How Typical is the German Experience?', German Politics, 10 (2): 99-116.

Mukesh, Chawla, Betcherman Gordon, and Banerji Arup (2007), From Red to Gray: The "Third Transition" of Ageing Populations in Eastern Europe and the former Soviet Union, World Bank: Washington, DC. Online at http://siteresources.worldbank.org/ECAEXT/Resources/publications/454763-

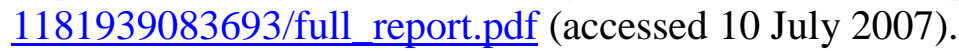

Novinite news agency (2007) 'Pensioners' Party Set Up In Bulgaria', 12 May. Online at http://www.novinite.com/view_news.php?id=80585 (accessed 11 October 2007).

Pierson, P (1996), 'The New Politics of the Welfare State', World Politics, 48 (2), 143-79 
Phelps, Edward (2006) 'Young Adults and Electoral Turnout in Britain: Towards a Generational Model of Political Participation', Sussex European Institute working paper No. 92.

Pop, Liliana and Pieter Vanhuysse (2004) 'Review Article: Varieties of Capitalism, Varieties of Theory? Conceptualizing Paths of Change and Patterns of Economic Interaction across Models of Market Democracy,' Journal of European Public Policy, 11 (1): 167-177.

Redding K and Jocelyn S Viterna (1999) 'Political Demands, Political Opportunity Structures and the Differential Success of Green Parties', Social Forces 78 (2), 491510 .

Robertson, Fiona 'Youth Political Participation in Poland and Romania'. Unpublished $\mathrm{PhD}$ thesis, University College London.

Rochon, Thomas A. (1985), 'Mobilizers and Challengers: Towards a Theory of New Party Success', International Political Science Review, 6 (4), 419-39.

Sikk, Allan (2005), 'How Unstable? Volatility and the Genuinely New Parties in Eastern Europe, European Journal of Political Research', 44(1): 391-412

Sikk, Allan (2006), Highways to Power: New Party Success in Three Young Democracies, Tartu: Tartu University Press, 2006.

Smith, Gordon (1991), 'In Search of Small Parties: Problems of Definition, Classification and Significance' in Ferdinand Müller-Rommel and Geoffrey Pridham (eds.) Small Parties in Western Europe: Comparative and National Perspectives, London: SAGE, 23-40.

Susser, Bernard (2007), 'The Retirees' (Gimla'im) Party: An "Escapist” Phenomenon?', Israel Affairs, 13 (1): 187-92.

Whiteley, Paul, Patrick Seyd, Jeremy John Richardson (1994), True Blues: the Politics of Conservative Party Membership, Oxford: Oxford University Press.

Tavits, Margit (2006) Party System Change: Testing a Model of New Party Entry." Party Politics, 12(1): 99-119.

Tavits, Margit (2008), 'Party Systems in the Making: The Emergence and Success of New Parties in New Democracies' British Journal of Political Science, 38(1): 113133.

Tepe, Markus and Vanhuysse, Pieter (2009), 'Are Aging Welfare States on the Path to Gerontocracy? Evidence from 18 OECD Democracies, 1980-2002,' Journal of Public Policy, 29 (1) 1-28.

Thornton, Guy (1995), 'Pillars of society shaken by political earthquake: The Dutch election - May 1994', Representation, 33 (3): 106 - 110. 
Time (1972), 'Symptoms of malaise', 20 March. Online at http://www.time.com/magazine/article0,9171,942501,00.html (accessed 1 May 2009).

Urquhart, Conal (2006) 'Youth contribute to success of group promoting rights of the elderly', The Guardian, 30 March.

van Stipdonk V.P. and J.J.M. van Holsteyn (1995), "Wat Ouderen Verbond, Verklaringen van het ontstaan en succes van een nieuwe partij", Jaarboek DNPP. Online at www.rug.nl/dnpp/jaarboeken/jaarboek1995 (accessed 1 July 2007).

Vanhuysse, Pieter (2001), 'Review Article: The Political Economy of Pensions: Western Theories, Eastern Facts,' Journal of European Public Policy, 8 (5): 853-861.

Vanhuysse, Pieter (2006), Divide and Pacify: Strategic Social Policies and Political Protests in Post-Communist Democracies. Budapest-New York: Central European University Press.

Večerník, Jiř́ (2006) 'Changing Social Status of Pensioners and Prospects of Pension Reform in the Czech Republic', Institute of Economic Studies, Charles University, Occasional Paper 2/2006.

Vincent, John. A., G. Patterson and K. Wale (2001) Politics and Old Age: Older Citizens and Political Processes in Britain. Ashgate: Basingstoke.

Vincent, John A (2003) 'Demography, Politics and Old Age', paper presented at the British Society for Gerontology Annual Conference, Newcastle upon Tyne, 4-6 September. Online at http://www.people.ex.ac.uk/JVincent/Conference\%20papers/BSG\%20Newcastle/New castle\%20Paper.doc (accessed 1 July 2007).

Viriot Durandal, Jean-Phillippe (2003), Le pouvoir gris, Paris: Presse universitaires de France.

Walker, Alan (1998), 'Speaking for themselves: the new politics of old age in Europe', Education and Ageing, 13 (1): 13-36.

Waller, Michael (1993), 'Political actors and political roles in East-Central Europe', Journal of Communist Studies and Transition Politics, 9 (4): 21-36.

Wang, Frank T. Y. (1999) 'Resistance and Old Age: the Subject Behind the American Seniors' Movement' in Adrienne S. Chambon, Allan Irving and Laura Epstein (eds), Reading Foucault for Social Work, New York, Columbia University Press, 189-218.

Willey, J. (1998), 'Institutional arrangements and the success of new parties in old democracies', Political Studies, 33:125-64.

Western Daily Press (2004), 'Grey Power Aiming to Shake Up Politics', 15 April Online at http://westpress.co.uk/new/util/content.jsp?id=9602626 (accessed 7 September 2007). 
Table 1: Pensioners parties in Western Europe and Israel

\begin{tabular}{|c|c|}
\hline Belgium & $\begin{array}{l}\text { Waardig Ouder Worden (WOW) } \\
\text { Founded } 1994 \\
\text { European elections } 19942.14 \% \\
\text { Flemish parliamentary elections 2004, 0.02\% }\end{array}$ \\
\hline Denmark & $\begin{array}{l}\text { Active Pensioners Party (Partiet Aktive Pensionister) } \\
\text { Founded } 1997 \\
\text { Contested local elections } 2005 \\
\text { Has not contested national elections }\end{array}$ \\
\hline Finland & $\begin{array}{l}\text { 1. Joint Responsibility Party of Pensioners and Greens } \\
\text { Parliamentary elections 1991, 0.1\% } \\
\text { 2. Independent Non-Aligned Pensioners in Finland } \\
\text { Parliamentary elections 1991, 0.19\% } \\
\text { 3. Pensioners for the People (EKA) } \\
\text { Parliamentary elections 1995, 0.2\% } \\
\text { Parliamentary elections } 19990.2 \% \\
\text { 4. Finnish Pensioners' Party (SEP - Suomen eläkeläisten } \\
\text { puolue) } \\
\text { 1987, 1.22\% } \\
\text { Parliamentary elections 1991, } 0.39 \% \\
\text { Parliamentary elections 1995, } 0.1 \% \\
\text { Parliamentary elections } 1999,0.2 \%\end{array}$ \\
\hline Germany & $\begin{array}{l}\text { 1. The Greys - Gray Panthers Die Grauen - Graue } \\
\text { Panther) } \\
\text { Founded } 1989 \text { (as pressure group 1975) } \\
\text { Formally dissolved in } 2008 \\
19900.8 \% \% \text { PR lists? } \\
19940.4 \% \text { Single Member Districts, 0.5\% PR lists } \\
19980.3 \% \text { Single Member Districts, 0.3\% PR lists } \\
20020.2 \% \text { Single Member Districts, 0,2 PR lists } \\
20050.0 \text { Single Member District (6340 votes), PR list } \\
0.4 \% \\
\text { 2004 European elections 1.2\% } \\
\text { 2. The Greys -Party of Generations (Die Grauen- } \\
\text { Generationspartei) } \\
\text { Founded 2008 } \\
\text { 3. Grey Panther Alliance (Allianz Graue Panther) } \\
\text { Founded 2008 }\end{array}$ \\
\hline Holland & $\begin{array}{l}\text { 1. General Elderly Alliance (Algemeen Ouderen Verbond, } \\
\text { AOV) } \\
\text { Founded } 1993 \\
1994 \text { parliamentary election, } 3.6 \% 6 \text { seats (of } 150 \text { ) } \\
\text { Did not contest subsequent parliamentary elections } \\
\text { Represented at sub-national (provincial) level (provincial } \\
\text { elections in } 1995-2003 \text { ). Gained seats in upper chamber } \\
1995-8 \text { on basis on provincial representation } \\
\text { 2. Union } 55+ \\
\text { Founded } 1992 \\
1994 \text { parliamentary election, } 0.8 \%, 1 \text { seat }\end{array}$ \\
\hline
\end{tabular}




\begin{tabular}{|c|c|}
\hline & $\begin{array}{l}\text { Sub-national (provincial) representation in coalition with } \\
\text { AOV } \\
\text { 3. Elderly Union (Ouderenunie). } \\
\text { Formed } 1998 \text { from merger of AOV and Union 55+ } \\
1998 \text { parliamentary election, } 0.5 \% \\
\text { 4. United Seniors Party (Verenigde Senioren Partij - } \\
\text { VSP) } \\
\text { Formed } 2001 \text { from merger of Elderly Union and Seniors } \\
\text { Party } \\
2002 \text { parliamentary elections } 0.4 \% \\
2003 \text { parliamentary elections - not contested } \\
2006 \text { parliamentary elections } 0.1 \% \\
\text { Limited sub-national representation }\end{array}$ \\
\hline Italy & $\begin{array}{l}\text { 1. Autonomous Party of Pensioners } \\
\text { Contested parliamentary elections } 1972 \\
\text { 2. Pensioners' Party: Partito Pensionati) } \\
\text { Founded } 1987 \\
1999 \text { European elections } 0.8 \% \text {, no seats } \\
2004 \text { European elections, } 1.1 \%, 1 \text { seat } \\
2006 \text { parliamentary elections, } 0.88 \% \text { Part of centre-left } \\
\text { Union grouping } \\
\text { 2008 parliamentary election - candidates presented as part } \\
\text { of People of Freedom bloc }\end{array}$ \\
\hline Israel & $\begin{array}{l}\text { 1. Older Persons and Pensioners Party of Israel } \\
\text { (HaGimlain Vhakshishim BeIsrael) } \\
\text { Founded } 1981 \\
1981 \text { parliamentary elections, } 0.1 \% \\
\text { 2. 'Pensioners' (Gimlaim) } \\
\text { Founded } 1988 \\
1988 \text { parliamentary elections, } 0.73 \% \\
1992 \text { parliamentary elections in coalition with Hand by } \\
\text { Hand (Yad beyad) party representing ex-Soviet } \\
\text { immigrants, 0.31\% } \\
\text { 3. Power for Pensioners (Koah LaGimlaim), parliamentary } \\
\text { elections } 1999,1.1 \% \text {, no seats } \\
\text { 4. Pensioners of Israel to the Knesset (GIL) Gimla'ey } \\
\text { Yisrael LaKnesset } \\
\text { Founded } 1996 \\
\text { 1996 parliamentary elections, } 0.57 \% \text {, } \\
\text { 2006 parliamentary elections, } 5.92 \%, 7 \text { seats (of 120) } \\
\text { 2009 parliamentary elections, } 0.52 \%\end{array}$ \\
\hline Luxembourg & $\begin{array}{l}\text { 1. Alternative Democratic Reform party (ADR)* } \\
\text { (Alternativ Demokratesch Reformpartei/ Parti réformiste } \\
\text { d'alternative démocratiquelAlternative Demokratische } \\
\text { Reformpartei) } \\
\text { Founded } 1987 \\
1989 \text { parliamentary elections } 7.3 \%, 4 \text { seats (of } 60 \text { ) } \\
1994 \text { parliamentary elections } 9.0 \%, 5 \text { seats } \\
1999 \text { parliamentary elections } 11.3 \%, 7 \text { seats } \\
2004 \text { parliamentary elections } 9.9 \% 5 \text { seats } \\
2009 \text { parliamentary elections, } 8,1 \% 4 \text { seats } \\
\text { Subnational representation since } 1993\end{array}$ \\
\hline
\end{tabular}




\begin{tabular}{|c|c|}
\hline & $\begin{array}{l}\text { 2. Party of the Third Age (Partei vum 3. Alter, Parti du } \\
\text { troisième age) } \\
1999 \text { parliamentary elections } 0.1 \% \\
2004 \text { parliamentary elections } 0.4 \% \text { in one constituency } \\
\text { Now disbanded }\end{array}$ \\
\hline Norway & $\begin{array}{l}\text { Pensioners Party (Pensjonistpartiet). } \\
\text { Founded } 1985 \text {. } \\
1985 \text { parliamentary elections } 0.3 \% \\
1989 \text { parliamentary elections } 0.3 \% \\
1993 \text { parliamentary elections } 1.0 \% \\
1997 \text { parliamentary elections } 0.6 \\
2001 \text { parliamentary elections } 0.7 \% \\
2005 \text { parliamentary election } 0.5 \% \\
\text { Never represented at national level. } \\
\text { Some subnational representation. }\end{array}$ \\
\hline Portugal & $\begin{array}{l}\text { Party of National Solidarity (Partido da Solidariedade } \\
\text { Nacional-PSN) } \\
\text { Founded } 1990 \\
1991 \text { Parliamentary elections } 1.7 \%, 1 \text { seat (of 230) } \\
1995 \text { Parliamentary elections } 0.2 \% \\
1999 \text { Parliamentary elections } 0.2 \% \\
2002 \text { Parliamentary elections } 0.0 \%\end{array}$ \\
\hline Spain & $\begin{array}{l}\text { Active Pensioners' Party (Partido de los Pensionistas en } \\
\text { Acción - PDLPEA } \\
\text { Founded } 2007 \\
2008 \text { parliamentary elections } 0.01 \%\end{array}$ \\
\hline Sweden & $\begin{array}{l}\text { Swedish Senior Citizen Interest Party (Sveriges } \\
\text { Pensionärers Intresseparti) } \\
\text { Founded } 1987 \\
1991 \text { parliamentary elections } 0.04 \% \\
1994 \text { parliamentary elections } 0.04 \% \\
1998 \text { parliamentary elections } 1.0 \% \\
2003 \text { parliamentary elections } 0.71 \% \\
2006 \text { parliamentary elections } 0.52 \% \text {. } \\
\text { Never represented at national level. } \\
\text { Some subnational representation }\end{array}$ \\
\hline $\begin{array}{l}\text { UK } \\
\text { - Scotland } \\
\text { - } \quad \text { England and Wales }\end{array}$ & $\begin{array}{l}\text { Scottish Senior Citizens Unity Party (SSCUP) } \\
\text { Founded } 2003 \\
2003 \text { Scottish parliamentary elections, } 0.1 \% \text { in Single } \\
\text { Member Districts, } 1.5 \% \text { of regional list votes, } 1 \text { seat } \\
2007 \text { Scottish parliamentary elections, } 1.92 \% \text { of regional } \\
\text { list vote, no seats }\end{array}$ \\
\hline & $\begin{array}{l}\text { Senior Citizens Party } \\
2005 \text { European elections }\end{array}$ \\
\hline
\end{tabular}

*Name since 2006. Previously 'Action Committee - 5/6 Pensions for All' (1987-9), 'Action Committee 5/6' (1989-92), 'Action Committee for Democracy and Pensions Justice' 
Sources: http://www.parties-and-elections.de; Iecovich 2002; Israeli Knesset;

http://www.knesset.gov.il/description/eng/eng_mimshal_res.htm; The Times, 5 May 2007; German Federal

Returning Officer http://www.bundeswahlleiter.de; www.electionresources.org; Statistics Norway www.ssb.no;

Swedish Election Authority www.val.se and personal communication 10 January 2008; Statistics Norway

www.ssb.no 
Table 2: Pensioners parties in Eastern Europe

\begin{tabular}{|c|c|}
\hline Bosnia and Herzegovinia & $\begin{array}{l}\text { 1. Pensioners' Party of Bosnia and Herzegovina (Stranka Penzionera Umirovljenika } \\
\text { BiH) } \\
\text { Parliamentary elections 2002, 1.4\%, } 2 \text { (of 140) in parliament of Federation of Bosnia } \\
\text { and Herzegovina (Croat-Bosnian entity); } 1 \text { seat (of 42) in Bosnian parliament (both } \\
\text { entities) } \\
\text { Parliamentary elections 2006, } 1.48 \% \text {, no representation in parliament of Federation of } \\
\text { Bosnia and Herzegovina or Bosnian parliament } \\
\text { 2. Pensioners' Party of the Republika Srpska (Penzionerska Stranka Republike } \\
\text { Srpske) } \\
\text { Parliamentary elections } 2002,1 \text { seat (of } 83 \text { ) in National Assembly of the Serb } \\
\text { Republic within Bosnia. } \\
\text { Parliamentary elections } 2006,2.49 \% \text { no seats in National Assembly of the Serb } \\
\text { Republic within Bosnia. }\end{array}$ \\
\hline Bulgaria & $\begin{array}{l}\text { Social Solidarity Movement } \\
\text { Founded May } 2007\end{array}$ \\
\hline Croatia & $\begin{array}{l}\text { Croatian Pensioners' Party (Hrvatska stranka umirovljenika, HSU) } \\
\text { Founded } 1996 \\
\text { Parliamentary election } 2003-4 \%, 3 \text { seats (of 151) } \\
\text { Parliamentary election } 2007-4.1 \% 1 \text { seat (of } 153 \text { ) } \\
\text { Some sub-national (communal/municipal) representation }\end{array}$ \\
\hline Czech Republic & $\begin{array}{l}\text { Pensioners for a Secure Life (Duchodci za životni jistoty, DŽJ )* } \\
\text { Parliamentary election } 1992 * *, 3.77 \% \\
\text { Parliamentary election } 1996,3.09 \% \\
\text { Parliamentary election } 1998,3.06 \% \\
\text { Parliamentary election } 2002,0.86 \% \\
\text { Some sub-national (communal/municipal) representation } \\
\text { Merged with Independent Democrats (ND) grouping } 2006\end{array}$ \\
\hline Estonia & $\begin{array}{l}\text { 1. Estonian Pensioners' Union (Eesti Pensionaride Liit) } \\
\text { Parliamentary elections 1992, 3.71\% } \\
\text { Some sub-national (communal/municipal) representation } \\
\text { 2. Estonian Pensioners and Families Union (Eesti Pensionäride ja Perede Liit) } \\
\text { Contested } 1995 \text { election as part of Coalition Party and Country People's Alliance } \\
\text { (KMÜ). Later renamed the Estonian Pensioners and Families Party (Eesti } \\
\text { Pensionäride ja Perede Erakond, EPPE). Merged with the Estonia People's Party in } \\
\text { 1999. }\end{array}$ \\
\hline Hungary & $\begin{array}{l}\text { Pensioners' Party (Nyugdijasok Partja, NYUP ) } \\
\text { Parliamentary elections } 1994,0.02 \% \text { (SMD) } \\
\text { Parliamentary elections } 2002,0.00 \% * * 8 \text { (SMD) }\end{array}$ \\
\hline Poland & $\begin{array}{l}\text { 1. Legnica Association of Pensioners and Invalids (Polski Zw. Emerytów, Rencistów } i \\
\text { Inw. O/W Legnica) Parliamentary elections } 1991-0.04 \% \\
\text { 2. Disabled, Retired Persons and Pensioners ("Niepelnosprawni, Emeryci i Rencisci") } \\
\text { Parliamentary elections } 1991-0.04 \% \\
\text { 3. National Party of Pensioners and Retired Persons (Krajowa Partia Emerytów I } \\
\text { Rencistów, KPEiR) } \\
\text { Parliamentary elections } 1997-2.18 \% \\
\text { 4. National Alliance of Pensioners and Retired Persons of the Polish Republic } \\
\text { (Krajowe Porozumienia Emerytów i Rencistów Rzeczypospolitej Polskiej, KPPiRRP) } \\
\text { Parliamentary elections } 1997-1.63 \%\end{array}$ \\
\hline Romania & $\begin{array}{l}\text { 1. Party of Pensioners of Romania (Partidul Pensionarilor din Romania, PPR) } \\
\text { Parliamentary election } 2000-0.66 \% \\
\text { 2. Popular and Social Protection Party (Partidul Popular şi al Protecţiei Sociale) }\end{array}$ \\
\hline
\end{tabular}




\begin{tabular}{|c|c|}
\hline & Parliamentary elections $2008-0.12 \%$ \\
\hline Russia & $\begin{array}{l}\text { Pensioners' Party**** (Partiya pensionerov, PP) } \\
\text { Parliamentary elections 1999, 1.95\% (national PR list), 0.71\% (SMDs), } 1 \text { deputy } \\
\text { elected in SMD } \\
\text { Alliance of Pensioners' Party and Russian Social Justice Party } \\
2003 \text { Parliamentary elections 3.1\% (national PR list), 0.5\% (SMDs) } \\
\text { Merged with Fair Russia bloc in } 2006\end{array}$ \\
\hline Slovakia & $\begin{array}{l}\text { 1. Party of Pensioners and the Socially Dependent (Strana dôchodcov a sociálne } \\
\text { odkázaných, SDSO ) } \\
\text { Founded May } 1995 \\
\text { Did not contest national election } \\
\text { Officially deregistered October } 2005 \\
\text { 2. Pensioners' Party of Slovakia (SDS - Strana dôchodcov Slovenska) } \\
\text { Formed October } 1995 \\
\text { Contested } 2002 \text { parliamentary elections on electoral list of Real Slovak National Party } \\
\text { (PSNS). No deputies } \\
\text { Officially deregistered October } 2005\end{array}$ \\
\hline Slovenia & $\begin{array}{l}\text { Democratic Party of Pensioners of Slovenia (Demokratična stranka upokojencev } \\
\text { Slovenije, DeSUS) } \\
\text { Parliamentary elections 1992, contested as part of United List of Social Democrats } \\
\text { (ZLSD), } 1 \text { seat } \\
\text { Parliamentary elections } 19964.32 \% 5 \text { seats (of 90) } \\
\text { Parliamentary elections } 2000,5.17 \%, 4 \text { seats } \\
\text { Parliamentary elections 2004, 4.0\%, } 4 \text { seats } \\
\text { Parliamentary elections 2008, 7.47\%, } 7 \text { seats } \\
\text { Incumbent since 2000 } \\
\text { 2000-4 - coalition with Liberal Democrats (LDS), United Social Democrats (ZSLD) } \\
\text { and Slovene People's Party. No ministerial portfolio, deputy speakership of } \\
\text { parliament. } \\
\text { 2004- date, coalition with Slovenian Democratic Party (SDS), New Slovenia - } \\
\text { Christian People's Party (NSi), Slovenian People's Party (SLS). } \\
\text { One ministerial portfolio (defence) }\end{array}$ \\
\hline Serbia & $\begin{array}{l}\text { Party of United Pensioners of Serbia (Partija ujedinenich pensionera Srbije, PUPS) } \\
\text { Founded } 2005 \\
2007 \text { parliamentary elections - (in coalition with Social Democratic Party) } 3.91 \% 5 \\
\text { seats (of 250) }\end{array}$ \\
\hline Ukraine & $\begin{array}{l}\text { Bloc of the Party of Pensioners of Ukraine (Blok Partii Pensioneriv Ukrainy - BPPU) } \\
\text { - coalition of Party of Pensioners of Ukraine and Party of Protection of Pensioners of } \\
\text { Ukraine } \\
2007 \text { parliamentary elections } 0.14 \%\end{array}$ \\
\hline
\end{tabular}

*Later the Party for a Secure Life (Strana za životní jistoty)

** Figures for election to Czech parliament (Czech National Council)

$* * * 685$ votes $(1245$ votes in 1994$)$

**** Subsequently merged with Rodina and other parties into Fair Russia bloc

Sources

Central Electoral Commission of Bosnia and Hercegovina http://www.izbori.ba;

Czech Central Election Commission (www.volby.cz); Essex Election Archive

(www.essex.ac.uk/elections); Russia Votes (www.russiavotes.org); Republic of Slovenia Electoral 
Commission (http://www.sigov.si/elections/rvk.html); Republic of Serbia Electoral Commission (http://www.rik.parlament.sr.gov.yu/index_e.htm); Slovak Ministry of the Interior as reported at http://www.civil.gov.sk/archiv/POLIT/zoz_psph_04072006.htm; 'Pensioners' Party Set Up in Bulgaria', Novinite news agency report, 12 May 2007,

http://www.novinite.com/view_news.php?id=80585; Slovenian Government Communication Office, 'Slovenia Gets Its Sixth Government', December 2000

http://www.ukom.gov.si/eng/slovenia/background-information/elections2000-government/;

http://volitve.gov.si/dz2008/en/rezultati/rezultati_slo.html; Central Europe Review, 29 November 1999

http://www.ce-review.org/99/23/estonianews23.html; Permanent Electoral Authority of Romania (www.roaep.ro/en/index.php) 